\title{
Toelichting evenwichtige belangenafweging in de jaarverslaggeving 2020 door Nederlandse pensioenfondsen
}

\author{
Wilfred Kevelam, Anne Laning
}

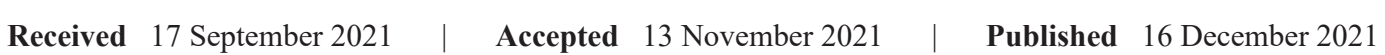

\section{Samenvatting}

Besturen van pensioenfondsen zijn op grond van de Pensioenwet verplicht om de belangen van de bij het pensioenfonds betrokken deelnemersgroepen en werkgever(s) evenwichtig af te wegen en hierover verantwoording af te leggen. Het intern toezichthoudend orgaan is belast met het toezien op de evenwichtige belangenafweging door het bestuur. In dit artikel hebben wij de kwaliteit van de verantwoording over de evenwichtige belangenafweging beoordeeld in de jaarverslaggeving over 2020 van vijftig Nederlandse pensioenfondsen. Wij concluderen dat de toelichtingen ten aanzien van de evenwichtigheid van het gevoerde beleid over het algemeen beperkt zijn en daarmee voor verbetering vatbaar. Ook hebben wij op basis van een vereenvoudigd model de mate van evenwichtigheid van het gevoerde beleid inzichtelijk gemaakt. Hieruit blijkt dat zogenoemde herverdelingseffecten tussen de verschillende deelnemersgroepen bij de meeste fondsen beperkt zijn. Er lijkt geen verband te zijn tussen de kwaliteit van de verantwoording over de evenwichtigheid en de mate van deze herverdelingseffecten.

\section{Relevantie voor de praktijk}

De dynamiek in de pensioensector is ongekend hoog en compliceert daarmee de wettelijke taak van pensioenfondsbestuurders om de belangen van alle bij het pensioenfonds betrokken deelnemersgroepen en werkgever(s) evenwichtig af te wegen. Het is daarom interessant te bezien op welke wijze het bestuur, het intern toezichthoudend orgaan en het verantwoordingsorgaan (of belanghebbendenorgaan) van pensioenfondsen verantwoording afleggen over de evenwichtigheid van het gevoerde beleid. Door middel van een aantal best practices illustreren wij hoe deze verantwoording heeft plaatsgevonden in de jaarverslaggeving over 2020. Mede met het oog op de aankomende transitie naar het nieuwe pensioenstelsel, waarin de evenwichtige belangenafweging een wezenlijke rol speelt, biedt deze bijdrage opstellers, controleurs en gebruikers van de jaarrekening daarmee waardevolle inzichten in de wijze waarop pensioenfondsen verantwoording afleggen over de evenwichtige belangenafweging.

\section{Trefwoorden}

pensioenfondsen, afleggen verantwoording, evenwichtige belangenafweging, jaarverslagen 2020

\section{Inleidling}

Al jarenlang is er veel maatschappelijke aandacht voor de financiële positie van pensioenfondsen, die sinds de financiële crisis van 2007/2008 is verslechterd. De belangrijkste oorzaken van de daling van de dekkingsgraden van pensioenfondsen zijn de stijgende levensverwachting en vooral de daling van de marktrente waarmee pensioenverplichtingen worden verdisconteerd, naar de mate waarin dit risico niet is afgedekt. Pensioenfondsen vallen onder de Pensioenwet en het daarop gebaseerde financieel toetsingskader (FTK). Hierin zijn de financiele spelregels voor pensioenfondsen opgenomen, onder andere bestaande uit verplichte toepassing van markt- 
waardering en eisen ten aanzien van de omvang van het vereiste eigen vermogen en maximale hersteltermijnen. De verslechterde financiële positie van pensioenfondsen heeft ertoe geleid dat pensioenen jarenlang voor een grote groep deelnemers niet meer zijn verhoogd of zelfs zijn verlaagd (korten). Het maatschappelijk vertrouwen in pensioenfondsen is daardoor aan erosie onderhevig.

Om het vertrouwen in het pensioenstelsel te herstellen, hebben kabinet en sociale partners in de zomer van 2020 overeenstemming bereikt over de hoofdlijnen van een nieuw pensioenstelsel. Uiterlijk 1 januari 2027 moet het nieuwe pensioenstelsel in werking treden. In december 2020 is het wetsvoorstel 'Wet toekomst pensioenen' ter consultatie aangeboden. Als onderdeel van dit wetsvoorstel zal het financieel toetsingskader gedurende de overgangsfase tijdelijk worden aangepast, het zogenoemde 'transitie-FTK'. In de aanloop naar het nieuwe pensioenstelsel gelden daarom aangepaste financiële spelregels, gericht op een evenwichtige transitie van het oude naar het nieuwe pensioenstelsel.

Voor pensioenfondsen is er daarom, vanuit het perspectief van financieel toezicht bezien, momenteel sprake van een complex 'interbellum'. Formeel geldt namelijk het huidige FTK, terwijl het transitie-FTK pas in werking treedt na de inwerkingtreding van de Wet toekomst pensioenen (naar verwachting 1 januari 2023). In het huidige FTK is onder meer opgenomen dat pensioenfondsen die op vijf achtereenvolgende balansdata een dekkingstekort hebben, de pensioenen moeten korten. Voor een groot aantal fondsen zou dit betekenen dat zij de pensioenen eind 2019 of eind 2020 hadden moeten verlagen. Echter, als onderdeel van het pensioenakkoord heeft minister Koolmees besloten dat de vrijstellingsregeling die voor 2019 is toegepast om pensioenkortingen te voorkomen, ook geldt voor boekjaar 2020 (zie 'Kamerbrief vrijstellingsregeling en transitie-FTK', 16 december 2020). Pensioenfondsen die gebruik willen maken van deze vrijstelling dienen per 31 december 2020 een actuele dekkingsgraad te hebben van minimaal $90 \%$. Daarnaast moeten pensioenfondsen aantonen en onderbouwen dat de belangen van alle deelnemers en pensioengerechtigden evenwichtig zijn afgewogen in de besluitvorming. Hierbij wordt met de blik van het nieuwe pensioenstelsel en het transitie-FTK gekeken naar de huidige situatie, om te voorkomen dat nu maatregelen worden getroffen die bij de transitie naar het nieuwe pensioenstelsel wellicht niet nodig zouden zijn.

De financiële positie van veel pensioenfondsen is al geruime tijd niet toereikend om een waardevast pensioen te bieden en de onzekerheid over de toekomstige mogelijkheden onder het nieuwe pensioenstelsel is groot. De verschillende betrokken partijen bij het pensioenfonds, waaronder actieve deelnemers, slapers, gepensioneerden en de werkgever(s), hebben daarbij verschillende belangen. Deze combinatie leidt tot complexiteit in de besluitvorming door pensioenfondsen. Voor pensioenfondsbestuurders is het daarom zaak hun beleidskeuzes zorgvuldig te maken, hierbij rekening te houden met de evenwichtige afweging van de belangen van alle betrokken partijen en hierover verantwoording af te leggen.

De verantwoording over de evenwichtige belangenafweging in de jaarverslaggeving over boekjaar 2020 staat in dit artikel centraal. Het belang van deze verantwoording wordt benadrukt door de Koninklijke Nederlandse Beroepsorganisatie van Accountants (NBA), die in februari 2021 voor het tweede jaar op rij een open brief publiceerde. In deze brief vraagt de NBA aandacht voor de verantwoording in het jaarverslag van pensioenfondsen van de risico's, onzekerheden en belangenafweging tijdens de overgangsperiode naar het nieuwe pensioenstelsel. In het bijzonder wordt aandacht gevraagd voor de toelichting op de evenwichtige afweging van de belangen van de betrokken partijen ingeval gebruik wordt gemaakt van de vrijstellingsregeling. Vervolgens is het ook interessant om te bezien op welke wijze het intern toezichthoudend orgaan en het verantwoordingsorgaan of, indien van toepassing, het belanghebbendenorgaan verantwoording afleggen over de toetsing van deze evenwichtigheid in hun verslag. Tot slot wordt onderzocht, op basis van de gegevens in de jaarrekening, wat de omvang is van de herverdelingseffecten tussen deelnemersgroepen, als indicator voor de evenwichtigheid van het beleid.

Deze bijdrage is verder als volgt gestructureerd: allereerst gaan wij nader in op het begrip evenwichtige belangenafweging en de van toepassing zijnde verslaggevingseisen hieromtrent (paragraaf 2). Vervolgens beschrijven wij in paragraaf 3 de wijze waarop het empirisch onderzoek is vormgegeven, waarbij wij ingaan op de onderzoeksmethodiek en de onderzoekspopulatie. Paragraaf 4 bevat de uitkomsten van ons onderzoek. Hierbij gaan wij eerst in op de verantwoording van de evenwichtige belangenafweging en de kwaliteit van de toelichtingen. Hierbij presenteren wij ook een aantal 'best practices'. Daarna gaan wij nader in op de financiële uitwerking van de belangenafweging, zoals deze af te leiden is uit de jaarverslaggeving over 2020 . We sluiten deze bijdrage af met een conclusie en nabeschouwing.

\section{Evenwichtige belangenafweging en verantwoording}

Evenwichtige belangenafweging is een belangrijk uitgangspunt dat wordt geborgd in de Pensioenwet (PW). ${ }^{1}$ De kern van dit principe wordt verwoord in artikel 105 lid 2 PW: "De personen die het beleid van een pensioenfonds bepalen of mede bepalen richten zich bij de vervulling van hun taak naar de belangen van de bij het pensioenfonds betrokken deelnemers, gewezen deelnemers, andere aanspraakgerechtigden, de pensioengerechtigden en de werkgever en zorgen ervoor dat dezen zich door hen op evenwichtige wijze vertegenwoordigd kunnen voelen." Met andere woorden, binnen de beleidsruimte die pensioenfondsbestuurders hebben dienen zij de sturingsinstru- 
menten zodanig in te zetten dat rekening wordt gehouden met de verschillende belangen van de betrokken partijen. Deze sturingsinstrumenten hebben voornamelijk betrekking op het premiebeleid, het beleggingsbeleid (inclusief renteafdekking) en het beleid over indexatie en kortingen (zie ook Langendijk and Laning 2011; Ter Hoeven and Laning 2010). Het behoeft geen betoog dat de belangen van deze groepen in gevallen onderling kunnen conflicteren: het is dan aan het bestuur van het pensioenfonds om hier een passend evenwicht in te vinden. Een verdere precisering hoe de verplichting tot de evenwichtige belangenafweging in de praktijk tot uiting gebracht moet worden, ontbreekt echter in de wetgeving.

Onder 'personen die het beleid van een pensioenfonds bepalen of mede bepalen' worden in de regel verstaan de leden van het bestuur van het fonds, maar ook de leden van de directie of het bestuursbureau, indien zij beschikken over een mandaat van het bestuur voor het nemen van bestuursbesluiten (Den Blanken and Panneman 2018). Het intern toezichthoudend orgaan - in de vorm van een raad van toezicht, niet-uitvoerende bestuurders of een visitatiecommissie - dient de evenwichtige belangenafweging door het bestuur mee te nemen in zijn toezichthoudende rol op basis van artikel 104 PW. Leden van het belanghebbendenorgaan of verantwoordingsorgaan zijn in beginsel geen (mede)beleidsbepalers en hebben ook geen formele toezichthoudende rol. In de Pensioenwet wordt aan hen de rol toebedeeld om een oordeel te geven over het handelen van het bestuur, over het door het bestuur gevoerde beleid, evenals de beleidskeuzes voor de toekomst (artikel 115a lid 2 PW). Dit oordeel dient opgenomen te worden in het bestuursverslag. Voor het belanghebbendenorgaan geldt een soortgelijke bepaling op basis van artikel 115c lid 7 PW.

De verantwoordelijkheid c.q. plicht tot een evenwichtige afweging van de belangen van betrokken partijen komt ook nadrukkelijk terug in de Code Pensioenfondsen. Dat blijkt direct uit de eerste norm van de Code: "Het bestuur voert de regeling naar beste vermogen uit, in een evenwichtige afweging van belangen, en heeft hiervoor de eindverantwoordelijkheid." In het besluitvormingsproces weegt het pensioenfondsbestuur de verschillende belangen af van de groepen die bij het pensioenfonds betrokken zijn en geeft het bestuur inzicht in de risico's van de belanghebbenden op korte en lange termijn. Op basis van norm 24 van de Code stelt iedere pensioenfondsbestuurder zich in de besluitvorming onafhankelijk op ten opzichte van zijn of haar eventuele achterban. Hij of zij handelt in het belang van alle belanghebbenden van het fonds. Een evenwichtig besluitvormingsproces houdt dan ook rekening met de korte- en langetermijneffecten van maatregelen op deelnemers, pensioengerechtigden, gewezen deelnemers, andere aanspraakgerechtigden en de werkgever(s). In de Code wordt de rol van het belanghebbendenorgaan jegens de evenwichtige belangenafweging benoemd en wel in norm 53. Hierin staat vermeld dat het belanghebbendenorgaan de evenwichtige afweging van de verschillende groepen door het bestuur dient te 'be- waken'. Opvallend is dat deze verplichting niet op het verantwoordingsorgaan rust.

Het afleggen van verantwoording over het gevoerde beleid is het sluitstuk (en daarmee een cruciaal element) van een effectief governanceproces. Het pensioenfondsbestuur legt verantwoording af over het beleid dat het voert, de gerealiseerde uitkomsten van dit beleid en de beleidskeuzes die het eventueel voor de toekomst maakt (zie norm 5 van de Code). De verantwoording waarop wij ons in dit artikel richten is de verantwoording in het jaarverslag. Hierbij dienen pensioenfondsen uiteraard rekening te houden met het verslaggevingskader dat voor pensioenfondsen van toepassing is. Zonder meer kunnen wij stellen dat dit verslaggevingskader inmiddels vrij complex is geworden, door een samenspel van verschillende verslaggevingsbronnen.

Artikel 146 PW kan als uitgangspunt voor de jaarverslaggeving door pensioenfondsen worden beschouwd. Dit artikel schrijft voor dat de jaarrekening en het bestuursverslag van een pensioenfonds moeten voldoen aan de bepalingen van Titel 9 van het Burgerlijk Wetboek 2 (BW2). De vrijstellingen voor de inrichting en publicatie van de jaarrekening voor kleine en middelgrote rechtspersonen zijn hierbij niet van toepassing. In Titel 9 BW2 is opgenomen dat de jaarrekening wordt opgesteld op basis van maatschappelijk aanvaarde normen. Hier is invulling aan gegeven door de Richtlijnen voor de Jaarverslaggeving (RJ). Voor pensioenfondsen is in het bijzonder Richtlijn 610 Pensioenfondsen relevant: deze richtlijn bevat specifieke bepalingen voor de inrichting van de jaarverslaggeving door pensioenfondsen. RJ 610 sluit zo veel mogelijk aan op de Pensioenwet en de hieraan gerelateerde Algemene Maatregelen van Bestuur (met name het FTK) om inconsistenties in verslaggeving te voorkomen.

Tezamen met de jaarrekening stelt het bestuur van een pensioenfonds ook een bestuursverslag op. De algemene verslaggevingsrichtlijnen hiervoor zijn opgenomen in RJ 400 Bestuursverslag, terwijl RJ 610 nog een aantal specifieke eisen bevat voor pensioenfondsen. Krachtens artikel 33 PW zijn pensioenfondsen ook gehouden aan de Code Pensioenfondsen die eveneens een aantal normen kent voor het bestuursverslag. Hierbij dient wel opgemerkt te worden dat de individuele bepalingen van de Code feitelijk geen bindende status hebben, omdat voor de naleving van de Code het 'pas toe of leg uit'-beginsel geldt.

In de Code Pensioenfondsen komt de verantwoording over evenwichtige belangenafweging expliciet terug in norm 5: "Het bestuur legt verantwoording af over het beleid dat het voert, de gerealiseerde uitkomsten van dit beleid en de beleidskeuzes die het eventueel voor de toekomst maakt. Het bestuur weegt daarbij de verschillende belangen af van de groepen die bij het pensioenfonds betrokken zijn. Ook geeft het bestuur inzicht in de risico's van de belanghebbenden op korte en lange termijn, gerelateerd aan het overeengekomen ambitieniveau." Uit de toelichting in de Code blijkt dat de bedoelde verantwoording en het inzicht in de risico's in ieder geval deel uitmaken van de jaarverslaggeving. 
Als we de bovengenoemde bronnen voor de jaarverslaggeving evalueren, dan valt op dat de concrete verslaggevingseisen ten aanzien van de evenwichtige belangenafweging beperkt zijn. Zowel in Titel 9 van het Burgerlijk Wetboek 2 als in RJ 610 ontbreken concrete toelichtingsvereisten op dit gebied. Wel wordt op basis van RJ 610.403 aanbevolen een beleidsmatige toelichting op de aanwezige risico's en het daarop gerichte beleid op te nemen in het bestuursverslag. Hierbij worden onder meer de toelichting op het premiebeleid, indexatiebeleid en het financieringsbeleid genoemd: beleidsaspecten die een directe relatie met de evenwichtige belangenafweging kennen. De genoemde toelichtingsvereisten zijn dus breed geformuleerd. Gezien de expliciete verankering van de evenwichtige belangenafweging in de Pensioenwet, bevreemdt het dat dit aspect niet expliciet terugkomt als toelichtingsvereiste in RJ 610. De centrale norm waaraan wij het bestuursverslag toetsen in dit onderzoek is derhalve bovengenoemde norm 5 uit de Code Pensioenfondsen.

Op basis van artikel 104 lid 2 PW en RJ 610.504 wordt in het bestuursverslag een verantwoording opgenomen van de raad van toezicht over de uitvoering van de taken en de uitoefening van de bevoegdheden. In dit verslag dient ook ingegaan te worden op de evenwichtige belangenafweging. Voor een intern toezicht in de vorm van een visitatiecommissie kent artikel 104 lid 8 PW eenzelfde bepaling.
RJ 610.504 vereist ook dat het oordeel van het verantwoordingsorgaan of het belanghebbendenorgaan over het handelen van het bestuur, het door het bestuur uitgevoerde beleid en over de beleidskeuzes voor de toekomst wordt opgenomen in het bestuursverslag (artikel $115 \mathrm{a}$ en $115 \mathrm{c}$ PW). Dit oordeel dient te worden voorzien van een reactie van het bestuur. Zoals opgemerkt, is in de Pensioenwet geen expliciete verantwoordelijkheid ten aanzien van de evenwichtige belangenafweging toegekend aan het verantwoordingsorgaan (of belanghebbendenorgaan). Er worden vanuit de Pensioenwet en RJ 610 dientengevolge ook geen eisen gesteld aan de verantwoording hieromtrent. In de Code wordt deze verantwoordelijkheid wel expliciet benoemd in norm 53 , waarbij overigens geen expliciete vereisten worden gesteld aan de verantwoording. Desalniettemin zullen wij in ons empirisch onderzoek kennisnemen van het verslag van zowel het intern toezichthoudend orgaan als het verantwoordingsorgaan (of belanghebbendenorgaan) en inzichtelijk maken in welke mate zij stilstaan bij de evenwichtige belangenafweging door het bestuur. In tabel 1 hebben wij de vereisten die gelden voor de verschillende fondsgremia ten aanzien van de evenwichtige belangenafweging en de verantwoording hierover samengevat.

Tabel 1. Samenvatting verantwoordelijkheden evenwichtige belangenafweging en verantwoording.

\begin{tabular}{|c|c|c|}
\hline Fondsorgaan & $\begin{array}{l}\text { Verantwoordelijkheid jegens evenwichtige } \\
\text { belangenafweging }\end{array}$ & Verantwoording over evenwichtige belangenafweging \\
\hline Bestuur & $\begin{array}{l}\text { Verantwoordelijkheid op basis van artikel } 105 \mathrm{PW} \text { om } \\
\text { zich bij de vervulling van zijn taak naar de belangen van } \\
\text { de bij het pensioenfonds betrokken partijen te richten. } \\
\text { Het bestuur voert de regeling naar beste vermogen uit, } \\
\text { in een evenwichtige afweging van belangen, en heeft } \\
\text { hiervoor de eindverantwoordelijkheid (norm } 1 \text { Code } \\
\text { Pensioenfondsen). } \\
\text { Het bestuur legt verantwoording af aan het } \\
\text { verantwoordingsorgaan (of belanghebbendenorgaan). }\end{array}$ & $\begin{array}{l}\text { Geen expliciete verantwoordingsverplichting op basis } \\
\text { van Titel } 9 \text { BW2 of RJ } 610 \text { Pensioenfondsen. } \\
\text { Het bestuur legt verantwoording af in het jaarverslag } \\
\text { over het beleid dat het voert, de gerealiseerde uitkomsten } \\
\text { van dit beleid en de beleidskeuzes die het eventueel } \\
\text { voor de toekomst maakt. Het bestuur weegt daarbij } \\
\text { de verschillende belangen af van de groepen die } \\
\text { bij het pensioenfonds betrokken zijn (norm } 5 \text { Code } \\
\text { Pensioenfondsen). }\end{array}$ \\
\hline Intern toezicht & $\begin{array}{l}\text { De raad van toezicht houdt toezicht op het beleid } \\
\text { van het bestuur en op de algemene gang van zaken } \\
\text { in het pensioenfonds. Dit omvat ten minste het } \\
\text { toezien op adequate risicobeheersing en evenwichtige } \\
\text { belangenafweging door het bestuur ( } 104 \text { lid } 2 \text { versus lid } \\
8 \mathrm{PW} \text { ). } \\
\text { De raad van toezicht legt verantwoording af aan het } \\
\text { verantwoordingsorgaan (of belanghebbendenorgaan). }\end{array}$ & $\begin{array}{l}\text { De raad van toezicht respectievelijk visitatiecommissie } \\
\text { legt verantwoording af over de uitvoering van de } \\
\text { taken en de uitoefening van de bevoegdheden in het } \\
\text { bestuursverslag ( } 104 \text { lid } 2 \text { resp. lid } 8 \mathrm{PW}) \text {. } \\
\text { Geen expliciete verantwoordingsverplichting op basis } \\
\text { van de Code Pensioenfondsen. }\end{array}$ \\
\hline $\begin{array}{l}\text { Verantwoordingsorgaan of } \\
\text { belanghebbendenorgaan }\end{array}$ & $\begin{array}{l}\text { Het verantwoordingsorgaan respectievelijk } \\
\text { belanghebbendenorgaan geeft een oordeel over het } \\
\text { handelen van het bestuur, over het door het bestuur } \\
\text { gevoerde beleid, evenals de beleidskeuzes voor de } \\
\text { toekomst (115a lid } 2 \mathrm{PW} \text { resp } 115 \mathrm{c} \text { lid } 7 \mathrm{PW} \text { ). } \\
\text { Het belanghebbendenorgaan bewaakt of het bestuur de } \\
\text { uitvoeringsovereenkomst of het uitvoeringsreglement en } \\
\text { het pensioenreglement juist uitvoert. Ook bewaakt het } \\
\text { belanghebbendenorgaan of het bestuur de belangen van } \\
\text { de verschillende groepen belanghebbenden evenwichtig } \\
\text { afweegt (norm } 53 \text { Code Pensioenfondsen). }\end{array}$ & $\begin{array}{l}\text { Het oordeel van het verantwoordingsorgaan } \\
\text { respectievelijk belanghebbendenorgaan over het } \\
\text { handelen en het beleid van het bestuur wordt opgenomen } \\
\text { in het bestuursverslag (artikel 115a en 115c PW en RJ } \\
610.504 \text { ). } \\
\text { Geen expliciete verantwoordingsverplichting over } \\
\text { evenwichtigheid op basis van de Pensioenwet of de } \\
\text { Code Pensioenfondsen. }\end{array}$ \\
\hline
\end{tabular}

Eerder wetenschappelijk onderzoek op het vlak van verantwoording over evenwichtige belangenafweging door pensioenfondsen is schaars. Langendijk and Laning (2011) hebben onderzoek gedaan naar de kwaliteit van de verantwoording over het beleggingsbeleid, premiebeleid en indexatiebeleid van 77 pensioenfondsen over boekjaar 2010. In dit onderzoek is ook de verantwoording over evenwichtige belangenafweging meegenomen. De con- 
clusie was dat op dat punt nog veel verbetering mogelijk was. Opgemerkt wordt dat het onderzoek heeft plaatsgevonden voor de inwerkingtreding van de Code Pensioenfondsen en de Wet versterking bestuur pensioenfondsen (beide 2014). Het is daarom zinvol te onderzoeken of de praktijk inmiddels verbetering laat zien.

\section{Opzet van het onderzoek}

\subsection{Onderzoeksmethodiek}

De kern van dit onderzoek is de kwaliteit van de verantwoording over de evenwichtige belangenafweging door het bestuur. Zoals gezegd, is in de regelgeving voor pensioenfondsen geen nadere invulling gegeven aan wat evenwichtig is, waardoor een norm voor evenwichtigheid ontbreekt. Vanuit de notie dat een pensioenfonds een doelvermogen is voor de verschillende groepen deelnemers, valt op basis van het jaarverslag wel inzicht te verkrijgen hoe het gevoerde pensioenfondsbeleid financieel uitpakt voor de betrokken deelnemers. Daarvoor gebruiken we in dit artikel het volgende, vereenvoudigde, model om de financiële impact van beleidskeuzes te beoordelen:

- Als de premie voor nieuwe opbouw in een boekjaar lager is dan de waarde van nieuwe opbouw in dat boekjaar (premiedekkingsgraad onder de $100 \%$, een 'verlies op premie'), dan is dat een voordeel voor de actieve deelnemers, en een nadeel voor alle deelnemers naar rato van de verdeling van de voorziening pensioenverplichting. Immers, de actieve deelnemers ontvangen een hogere tegenprestatie dan de premie die voor hen wordt ingelegd, en alle deelnemers (inclusief diezelfde actieven) dragen hier de last van. Ondanks dat in de praktijk de premie gedeeld wordt tussen werkgever(s) en actieve deelnemers, hebben we dit effect toegerekend aan de actieve deelnemers, omdat de werkgeverspremie uit dezelfde loonruimte komt.

- Indien de gemiddelde dekkingsgraad over een boekjaar lager is dan $100 \%$, en de uitkeringen worden volledig betaald, dan leidt dit tot een 'verlies' op uitkeringen. Dit is een voordeel voor de pensioengerechtigden, en een nadeel voor alle deelnemers naar rato van de verdeling van de voorziening pensioenverplichting. Immers, de pensioengerechtigden ontvangen meer dan er op dat moment voor die uitkeringen in het fonds aanwezig is en alle deelnemers (inclusief diezelfde pensioengerechtigden) dragen hier de last van.

- Indien de actieve deelnemers met een ander percentage geïndexeerd worden dan de gewezen deelnemers en pensioengerechtigden, is dat ook een herverdelingseffect vanuit het vermogen van het pensioenfonds.

Bovenstaande effecten zijn in principe symmetrisch, in ieder geval symmetrisch te meten in de vorm van 'rekeningen-courant' tussen groepen deelnemers. Zoals ge- zegd, is dit een gestileerd model, aangezien de beleidsruimte van het bestuur beperkt is door regelgeving en afspraken tussen sociale partners. Desalniettemin biedt dit model een mogelijkheid om de effecten van beleidskeuzes op basis van de jaarverslagen inzichtelijk te maken en te vergelijken tussen pensioenfondsen. Een indicator voor evenwichtigheid is dan de mate waarin deze rekeningen-courant in evenwicht zijn. Vervolgens kan dit model gebruikt worden om deze effecten te vergelijken met de mate van afleggen van verantwoording door organen van het pensioenfonds. Een diepgaand onderzoek naar dit verband valt echter buiten het bestek van dit artikel.

Wat in bovenstaand model ontbreekt, is de invloed van het beleggingsbeleid, inclusief het beleid ten aanzien van renteafdekking. De uitkomst van het beleggingsbeleid is uiteraard in sterke mate afhankelijk van de ontwikkelingen op de financiële markten en daarmee niet ex ante bekend. Hiermee zijn dus ook de gevolgen voor de verschillende deelnemersgroepen niet vooraf in te schatten door het bestuur. Daarnaast geldt dat de uitkomsten van het beleggingsbeleid alle deelnemersgroepen in gelijke mate raken, waardoor er geen herverdelingseffecten tussen deelnemersgroepen aanwezig zijn. Bij de drie hiervoor genoemde onderdelen (premiebeleid, uitkeringsbeleid en indexatiebeleid) is de ex-anterichting van het beleid veelal wel bekend en ontstaan er als gevolg van het beleid wel herverdelingseffecten tussen deelnemersgroepen. Omdat het beleggingsbeleid, inclusief de mate van renteafdekking, wel van grote invloed is op de financiële resultaten van een pensioenfonds, nemen we dit aspect wel mee in de beoordeling van de verantwoording.

Voor de beoordeling van de verantwoording analyseren wij drie onderdelen van het jaarverslag: de verantwoording door het bestuur, het oordeel van het intern toezicht (raad van toezicht respectievelijk visitatiecommissie) en het oordeel van het verantwoordingsorgaan respectievelijk het belanghebbendenorgaan. Daarbij beoordelen wij in welke mate de evenwichtigheid van het beleid wordt geduid. Dit is een vereenvoudiging van de door Langendijk and Laning (2011) gebruikte schaalverdeling. Indien een pensioenfonds zowel een kwalitatieve als kwantitatieve duiding voor de evenwichtigheid geeft, zullen we dat aanmerken als kwantitatief, waardoor elk punt op de schaal wederzijds uitsluitend is. Voor het intern toezicht en het verantwoordingsorgaan beoordelen wij de vermelding van het oordeel over de evenwichtigheid (geen vermelding, niet evenwichtig, deels evenwichtig, evenwichtig). Dit aspect is in het onderzoek van Langendijk and Laning (2011) niet meegenomen, omdat deze governancestructuren destijds nog in ontwikkeling waren.

\subsection{Onderzoekspopulatie}

Het uitgangspunt voor ons empirisch onderzoek naar de jaarverslagen van pensioenfondsen over 2020 vormt de totale populatie van pensioenfondsen. Om tot een selectie van de te onderzoeken fondsen te komen baseren wij ons in eerste instantie op het bestand met openbare gegevens 
van individuele pensioenfondsen over boekjaar 2019 die DNB gepubliceerd heeft (het bestand met gegevens over boekjaar 2020 kwam te laat beschikbaar voor dit artikel). Dit bestand bevat reeds een aantal relevante gegevens over de pensioenfondsen voor de stratificatie van de te onderzoeken populatie. Dit bestand hebben wij vervolgens aangevuld met andere relevante gegevens uit de publicatie van DNB met kwartaalcijfers over het vierde kwartaal van 2020 van individuele pensioenfondsen: de omvang belegd vermogen eind 2020, de beleidsdekkingsgraad eind 2020 en de mate van renteafdekking eind 2020. Dit leidt tot een bestand met 212 pensioenfondsen. Voor 48 fondsen zijn niet alle benodigde gegevens in het bestand opgenomen, waardoor de resterende populatie 164 pensioenfondsen omvat. Dit betreft zowel ondernemingspensioenfondsen, bedrijfstakpensioenfondsen, beroepspensioenfondsen als individuele kringen van algemene pensioenfondsen.

Uit deze populatie van 164 pensioenfondsen beogen wij een zo breed mogelijke deelwaarneming te nemen om zo tot een representatieve weergave van de volledige pensioensector te komen. Om tot deze deelwaarneming te komen, hebben wij 164 pensioenfondsen ingedeeld op basis van de beleidsdekkingsgraad, de premiedekkingsgraad en de mate van renteafdekking van het fonds. Voor elk van deze parameters hebben wij de mediaan bepaald en vervolgens pensioenfondsen ingedeeld in 'hoger' of 'lager' dan de mediaan. Ook hebben wij de pensioenfondsen verdeeld in grote, middelgrote en kleine pensioenfondsen. Deze indeling leidt uiteindelijk tot 24 permutaties of subgroepen $(2 \times 2 \times 2 \times 3=24)$. Als uitgangspunt hebben wij per subgroep in principe twee pensioenfondsen geselecteerd. Als een subgroep niet toereikend is voor deze deelwaarneming, of meer dan tien fondsen kent, hebben wij dit aantal aangepast om tot een populatie van vijftig pensioenfondsen te komen. De selectie van fondsen binnen de subgroepen heeft willekeurig plaatsgevonden op basis van een randomizer.

In tabel 2 tonen we de verdeling van de populatie en de deelwaarneming naar de verschillende subgroepen. De namen van de geselecteerde pensioenfondsen zijn opgenomen in bijlage 1. De fondsen in de onderzoekspopulatie hebben een gezamenlijk balanstotaal van 250 miljard euro en hebben samen 1.560.000 deelnemers. De mediane beleidsdekkingsgraad eind 2020 van deze fondsen bedroeg 101,7\% (2019: 107,2\%) en de mediane premiedekkingsgraad eind 2020 93,9\% (2019: 100,0\%). De mediane mate van renteafdekking eind 2020 bedroeg $49,2 \%$ (2019: 48,6\%).

Tabel 2. Overzicht opbouw populatie en deelwaarneming.

\begin{tabular}{|c|c|c|c|c|c|}
\hline Beleidsdekkingsgraad & Premiedekkingsgraad & Renteafdekking & $\begin{array}{l}\text { Omvang fonds in } \\
\text { belegd vermogen }\end{array}$ & Populatie & Deelwaarneming \\
\hline \multirow[t]{12}{*}{ Boven mediaan } & Boven mediaan & Boven mediaan & Klein & 8 & 2 \\
\hline & & & Middel & 9 & 2 \\
\hline & & & Groot & 11 & 3 \\
\hline & & Onder mediaan & Klein & 3 & 2 \\
\hline & & & Middel & 7 & 2 \\
\hline & & & Groot & 4 & 2 \\
\hline & Onder mediaan & Boven mediaan & Klein & 5 & 2 \\
\hline & & & Middel & 8 & 2 \\
\hline & & & Groot & 5 & 2 \\
\hline & & Onder mediaan & Klein & 5 & 2 \\
\hline & & & Middel & 4 & 2 \\
\hline & & & Groot & 9 & 2 \\
\hline \multirow[t]{12}{*}{ Onder mediaan } & Boven mediaan & Boven mediaan & Klein & 13 & 3 \\
\hline & & & Middel & 5 & 2 \\
\hline & & & Groot & 1 & 1 \\
\hline & & Onder mediaan & Klein & 8 & 2 \\
\hline & & & Middel & 7 & 2 \\
\hline & & & Groot & 2 & 2 \\
\hline & Onder mediaan & Boven mediaan & Klein & 5 & 2 \\
\hline & & & Middel & 6 & 2 \\
\hline & & & Groot & 3 & 2 \\
\hline & & Onder mediaan & Klein & 6 & 2 \\
\hline & & & Middel & 7 & 2 \\
\hline & & & Groot & 23 & 3 \\
\hline Totaal & & & & 164 & 50 \\
\hline
\end{tabular}

\section{Onderzoeksresultaten}

\subsection{Verantwoording in bestuursverslag}

Wij beginnen met een beschrijving van de onderzoeksresultaten met betrekking tot het bestuursverslag. Uit tabel
3 blijkt dat de toelichtingen in het bestuursverslag met betrekking tot de evenwichtige belangenafweging relatief beperkt zijn. Het valt direct op dat acht pensioenfondsen (16\%) geen expliciet oordeel hebben over de evenwichtigheid van het gevoerde beleid. Dit is toch opmerkelijk, gezien het belang van dit onderwerp in relatie tot de bij- 
zondere omstandigheden die het boekjaar 2020 kenmerken. Overigens wil dit niet zeggen dat de evenwichtigheid helemaal niet wordt benoemd in het jaarverslag, maar het ontbreekt aan een concreet oordeel of het gevoerde beleid evenwichtig heeft uitgepakt voor de deelnemers. de strategische doelen. Zo staat in de visie van het fonds vermeld: "We willen een divers, kundig en paritair bestuur dat een afspiegeling is van de deelnemers, dat bij besluitvorming de mening van ieder bestuurslid serieus neemt en meeweegt, dat besluiten neemt op basis van

Tabel 3. Resultaten verantwoording in het bestuursverslag.

\begin{tabular}{|c|c|c|c|c|c|c|}
\hline \multirow[t]{2}{*}{ Score } & \multirow[t]{2}{*}{ Omschrijving } & \multicolumn{4}{|c|}{ Aantal pensioenfondsen } & \multirow{2}{*}{$\begin{array}{l}\text { Percentage van de } \\
\text { populatie }\end{array}$} \\
\hline & & Klein & Middel & Groot & Totaal & \\
\hline 0 & $\begin{array}{l}\text { Geen vermelding van evenwichtigheid van het } \\
\text { beleid }\end{array}$ & 5 & 1 & 2 & 8 & $16 \%$ \\
\hline 1 & Alleen vermelding dat het beleid evenwichtig is & 7 & 10 & 10 & 27 & $54 \%$ \\
\hline 2 & $\begin{array}{l}\text { Kwalitatieve duiding van de evenwichtigheid van } \\
\text { het beleid }\end{array}$ & 5 & 5 & 5 & 15 & $30 \%$ \\
\hline 3 & $\begin{array}{l}\text { Naast kwalitatieve ook kwantitatieve duiding van de } \\
\text { evenwichtigheid van het beleid }\end{array}$ & 0 & 0 & 0 & 0 & $0 \%$ \\
\hline Totaal & & 17 & 16 & 17 & 50 & $100 \%$ \\
\hline
\end{tabular}

De meerderheid van de pensioenfondsen volstaat met een korte vermelding dat het gevoerde beleid naar de mening van het bestuur 'evenwichtig' is (54\%). Daarnaast zijn er 15 pensioenfondsen (30\%) die in aanvulling op deze vermelding een kwalitatieve toelichting opnemen. Er zijn evenwel geen pensioenfondsen die de evenwichtigheid van het beleid kwantitatief onderbouwen en toelichten.

Een voorbeeld van een toelichting op de evenwichtige belangenafweging is opgenomen in figuur 1. De toelichting in het jaarverslag van Stichting Heineken Pensioenfonds valt in positieve zin op door de duidelijke uitwerking van de evenwichtige belangenafweging in relatie tot de missie en visie van het fonds, en de realisatie van objectiviteit en evenwichtige afweging van de belangen van verschillende deelnemersgroepen en werkgever, en dat open, transparant en benaderbaar is voor alle belanghebbenden." De deskundigheid en samenstelling (in termen van zowel diversiteit als pariteit) van het bestuur worden hier duidelijk als waarborg voor een evenwichtige besluitvorming beschouwd. Het bestuur geeft aan, mede op basis van een zelfevaluatie, dat in de besluitvorming de belangen van alle betrokken partijen evenwichtig zijn afgewogen. Dit wordt bevestigd in de rapportages van het verantwoordingsorgaan en de raad van toezicht.

Veel pensioenfondsen relateren de evenwichtige belangenafweging expliciet aan het beleggingsbeleid, toe-

Figuur 1. Best practice toelichting evenwichtige belangenafweging: Stichting Heineken Pensioenfonds, Jaarverslag 2020 , p. 145. https://heinekenpensioenfonds.nl/wp-content/uploads/2021/06/Heineken-Pensioenfonds-jaarverslag-2020.pdf

\title{
Evenwichtige belangenafweging
}

\begin{abstract}
Het uitgangspunt bij de beleidsbepaling door het bestuur is de evenwichtige afweging van de belangen van alle bij het fonds betrokken partijen. De belangen van alle groepen worden in gelijke mate in het oog gehouden. Bij elk belangrijk besluit worden de diverse (en mogelijk tegenstrijdige) belangen expliciet in beeld gebracht, net als de specifieke risico's voor iedere groep en de normen voor de afweging van de diverse belangen. Besluiten mogen de belangen van bepaalde betrokkenen niet onevenredig schaden. Daarbij hoort dat de intergenerationele gevolgen in het oog worden gehouden bij de besluitvorming.
\end{abstract}

\section{STRATEGISCH SUBDOEL BEHORENDE BIJ: WE HEBBEN EEN DIVERS, KUNDIG EN PARITAIR BESTUUR:}

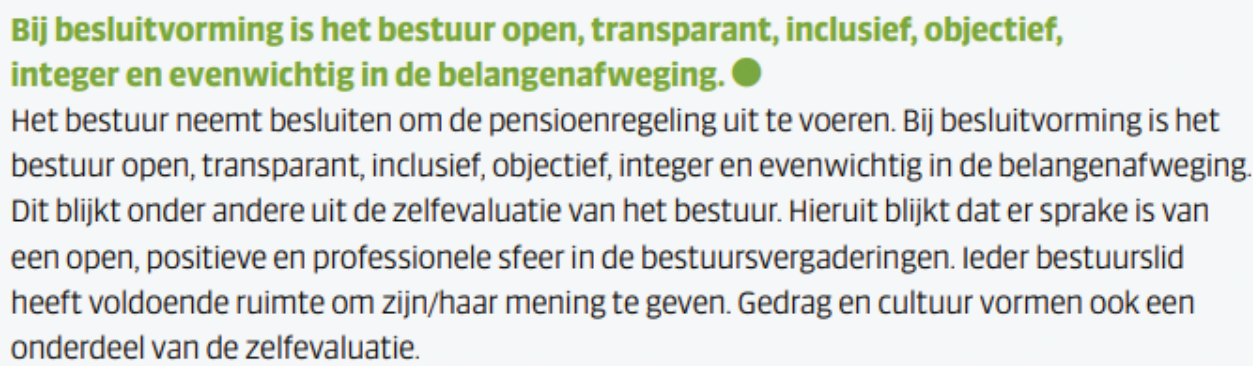


slagbeleid en/of premiebeleid. Met name het premiebeleid komt vaak en uitgebreid terug. Dit is niet onlogisch, aangezien door de lage rentestand de opbouw van nieuwe pensioenaanspraken duurder wordt. Hierdoor is de premiedekkingsgraad van veel pensioenfondsen (aanmerkelijk) lager dan $100 \%$, waardoor er sprake is van een verlies op premies voor het pensioenfonds. Om deze verliezen te beperken kunnen premies worden verhoogd ofwel opbouwpercentages worden verlaagd, waarbij afstemming met en veelal instemming van sociale partners vereist zijn. Dit heeft uiteraard uiteenlopende consequenties voor de verschillende deelnemersgroepen. De spanning tussen de driehoek premie, opbouw en dekkingsgraad is dus bij uitstek een vraagstuk waarbij de evenwichtige belangenafweging zich doet voelen.
Het ligt dan ook voor de hand dat pensioenfondsen stilstaan bij de evenwichtige belangenafweging in het kader van het premiebeleid. Een goed voorbeeld is wat ons betreft de toelichting in het jaarverslag van Stichting Pensioenfonds voor de Architectenbureaus (figuur 2 ). Het bestuur licht toe welke overwegingen ten grondslag liggen aan de conclusie van het bestuur om een lage premiedekkingsgraad te accepteren. Noemenswaardig is verder dat het fonds aan het begin van het jaarverslag een 'Pensioendashboard' heeft opgenomen, waarin de belangrijkste zaken in één oogopslag worden toegelicht. In dit dashboard wordt duidelijk vermeld dat de premiedekkingsgraad laag is, maar dat het bestuur concludeert dat de premie voor alle belanghebbenden evenwichtig is vastgesteld.

Figuur 2. Best practice toelichting evenwichtigheid premiebeleid: Stichting Pensioenfonds voor de Architectenbureaus, Jaarverslag 2020, p. 16. https://www.architectenpensioen.nl/images/pfab-jaarverslag-2020.pdf

\section{Evenwichtigheid van het premiebeleid \\ We behartigen de belangen van alle betrokkenen zo evenwichtig mogelijk. Hierdoor accepteren we een lage premiedekkingsgraad. Ondanks dat de premie in 2020 niet de volledige toename van de voorziening dekte, hebben we geconcludeerd dat de premie voldoet aan de voorwaarden van de evenwichtige belangenafweging. Daarbij hebben we het volgende overwogen:}

- Voor de premieberekening worden realistische verwachte rendementen gehanteerd. Deze worden ook gebruikt in het herstelplan om te bepalen of het herstel voldoende is om niet te hoeven korten.

- De gehanteerde verwachte rendementen waren in 2020 lager dan het maximum dat DNB toestaat. De afgelopen jaren zijn de daadwerkelijk behaalde rendementen hoger geweest.

- Omdat de opgebouwde rechten van premiebetalers pas na lange tijd tot uitkering komen, kunnen we op verantwoorde wijze meer in zakelijke waarden beleggen. Dit verbetert het perspectief op uitkering voor alle (gewezen) deelnemers en pensioengerechtigden.

- De premie heeft slechts een beperkte invloed op de financiële positie van het fonds.

De evenwichtigheid van ons premiebeleid hebben we tevens beoordeeld aan de hand van de aanvangshaalbaarheidstoets die in 2015 is uitgevoerd. Op grond van de resultaten hebben we geconcludeerd dat het premiebeleid evenwichtig uitpakt voor alle deelnemers in alle leeftijdscohorten omdat in het algemeen de tijd tussen het moment van premiebetaling en het ontvangen van een uitkering voldoende is om met het gemaakte rendement de kosten van de opbouw te kunnen dekken.

Een ander onderwerp waarbinnen de evenwichtige belangenafweging naar voren komt, is de keuze van pensioenfondsbesturen om al dan niet gebruik te maken van de vrijstellingsregeling van de minister. Fondsen die van deze mogelijkheid gebruikmaken kiezen er dus voor om de pensioenen niet te verlagen (korten), terwijl dit onder de reguliere voorschriften van het FTK wel verplicht zou zijn. Gezien het bijzondere en unieke karakter van de vrijstellingsregeling is het interessant te bezien hoe dit aspect terugkomt in de jaarverslaggeving over 2020.

In onze onderzoekspopulatie zijn negen pensioenfondsen (18\%) opgenomen die gebruik hebben gemaakt van de vrijstellingsregeling. Al deze fondsen staan in hun jaarverslag stil bij dit besluit. Hierbij zien wij overigens wel aanzienlijke verschillen in de kwaliteit en omvang van de toelichting. Zo benoemen niet alle fondsen het percentage waarmee de pensioenen gekort hadden moeten worden als de minister geen vrijstellingsmogelijkheid had geboden.

De toelichting in het jaarverslag van Stichting Pensioenfonds van de Metalektro (PME) beschouwen wij als 'best practice'. Het fonds vangt aan met een duidelijke toelichting op de financiële positie van het fonds en de mededeling dat voor het zesde jaar op rij niet wordt voldaan aan het minimaal vereist vermogen. Vervolgens licht het fonds toe dat het gebruikmaakt van de vrijstellingsregeling en dat het voldoet aan de voorwaarden die hieraan worden gesteld. Ook dient het fonds te onderbouwen waarom het vanuit het belang van deelnemers, gewezen deelnemers, andere aanspraakgerechtigden en pensioengerechtigden gebruikmaakt van de vrijstelling. De uitleg die hierop volgt is opgenomen in figuur 3 . Wij ontwaren 
een aantal positieve aspecten in deze toelichting. Allereerst komen alle informatie-elementen die wij redelijkerwijs mogen verwachten terug in de toelichting. Daarnaast worden in een overzichtelijke tabel de effecten van de toepassing van de vrijstellingsregeling per deelnemersgroep vermeld. De tabelvorm verhoogt naar onze mening de leesbaarheid van de toelichting. Tot slot staat het fonds expliciet stil bij waartoe het besloten zou hebben zonder toepassing van de vrijstellingsregeling. Alsdan had het bestuur een korting van 6,4\% moeten doorvoeren, waarbij het mogelijk onderscheid had gemaakt in het verlagingspercentage per deelnemersgroep.

Figuur 3. Best practice toelichting toepassing vrijstellingsbesluit: Stichting Pensioenfonds van de Metalektro, Jaarverslag 2020, p. 99. https://www.pmepensioen.nl/publicaties/media/1802/pmejaarverslag2020.pdf

PME besloot voor het tweede jaar op rij gebruik te maken van deze vrijstellingsregeling (zie paragraaf 1.2.5 van het bestuursverslag, onder kopje actualisatie van het herstelplan). Dit betekent dat PME in 2021 de pensioenaanspraken en uitkeringen niet hoeft te verlagen. In het besluitvormingsproces is gekeken naar de evenwichtigheid van het besluit. Het bestuur concludeerde dat gebruikmaken van de vrijstellingsregeling, mede gezien het thans bekende transitie-ftk, evenwichtig is voor alle groepen. Het leidt er toe dat een verlaging van de opgebouwde pensioenrechten en -aanspraken met $6,4 \%$ wordt voorkomen. Deze beslissing heeft geen gevolgen voor de continuïteit van het fonds. Doorrekening van het thans bekende transitie-ftk en de UFR-effecten laat zien dat het onzeker is of verlagingen tot 1 januari 2026 nodig zijn. Dit is (mede) afhankelijk van het gerealiseerde overrendement. Ook de fondsspecifieke richtdekkingsgraad speelt een rol, deze is echter nu nog niet vast te tellen. Omdat de regeling slechts voor één jaar geldt kan een verlaging in 2022 alsnog actueel zijn (voor meer informatie zie hoofdstuk 1.3 van het bestuursverslag). In 2021 worden de ingegane pensioenen volledig uitgekeerd. Uitgaande van de dekkingsgraad per 31 december 2020 is het effect hiervan op de financiële positie van het fonds voor 2021 beperkt.

\begin{tabular}{|c|c|}
\hline & Onderbouwing per groep \\
\hline $\begin{array}{l}\text { Pensioen- } \\
\text { gerechtigden }\end{array}$ & $\begin{array}{l}\text { Door de vrijstelling worden de uitkeringen in } 2021 \text { niet verlaagd (met 6,4\%). De } \\
\text { effecten op de financiële positie in } 2021 \text { zijn beperkt, omdat de dekkingsgraad bijna } \\
100 \% \text { is. }\end{array}$ \\
\hline Actieven & $\begin{array}{l}\text { Door de vrijstelling worden de aanspraken van de actieven in } 2021 \text { niet verlaagd. De } \\
\text { opbouw is voor de actieven in } 2021 \text { wel verlaagd naar 1,815\% door de nieuwe } \\
\text { gedempte rente in de premie. }\end{array}$ \\
\hline $\begin{array}{l}\text { Gewezen } \\
\text { deelnemers }\end{array}$ & De aanspraken van de gewezen deelnemers worden in 2021 niet verlaagd. \\
\hline Fonds & $\begin{array}{l}\text { De dekkingsgraad blijft volgens de verwachting in } 2021 \text { stabiel en blijft daarmee } \\
\text { boven de richtdekkingsgraad van } 95 \% \text { van het thans bekende transitie-ftk. }\end{array}$ \\
\hline $\begin{array}{l}\text { Sociale } \\
\text { Partners }\end{array}$ & $\begin{array}{l}\text { Voor sociale partners zijn de premie en opbouw van belang. De premie stijgt in } 2021 \\
\text { (en 2022), de opbouw voor deelnemers is gedaald naar 1,815\% }\end{array}$ \\
\hline
\end{tabular}

Gezien deze argumenten acht het bestuur van PME het evenwichtig om de verlaging nu niet door te voeren.

Als minister Koolmees in 2020 de tijdelijke vrijstellingsregeling niet had verlengd, dan had PME de pensioenen in 2021 moeten verlagen. Omdat de actuele dekkingsgraad eind $202097,6 \%$ is, zouden de pensioenen in 2021, op basis van de huidige wetgeving, met $6,4 \%$ zijn verlaagd. Hierdoor zou de actuele dekkingsgraad van PME naar 104,3\% gestegen zijn. Het bestuur bepaalde eerder in 2019 geen onderscheid in het verlagingspercentage te maken tussen groepen actieven, gewezen deelnemers en pensioengerechtigden bij een verlaging van de pensioenen in 2020. Het bestuur hield in 2020 het onderscheid maken in verlagingspercentages tussen de groepen nadrukkelijk wel als mogelijkheid open. De verlaging van $6,4 \%$ zou ook gespreid mogen worden over meerdere jaren (maximaal tien jaar). Op basis van eerder in 2019 vastgestelde uitgangspunten had het bestuur van PME er dan voor gekozen om deze verlaging in 2021 voor pensioengerechtigden over twee jaar te spreiden. 
4.2 Verantwoording door het intern toezicht en verantwoordingsorgaan

In paragraaf 2 van dit artikel hebben wij de formele rol van het intern toezichthoudend orgaan van een pensioenfonds en het verantwoordingsorgaan respectievelijk belanghebbendenorgaan toegelicht (voor de leesbaarheid van het artikel verwijzen wij in het vervolg enkel naar het verantwoordingsorgaan).

De raad van toezicht dient op basis van de Pensioenwet toe te zien op de evenwichtige belangenafweging door het bestuur en verantwoording af te leggen in het bestuursverslag over de uitvoering van zijn toezichtstaken. Voor het verantwoordingsorgaan geldt dat de Code Pensioenfondsen van hen vraagt te bewaken of het bestuur de belangen van de verschillende deelnemersgroepen evenwichtig afweegt. Het oordeel van het verantwoordingsorgaan over het handelen en het beleid van het bestuur dient ook te worden opgenomen in het jaarverslag.

Als onderdeel van het empirisch onderzoek hebben wij derhalve ook de rapportages van het intern toezichthoudend orgaan en het verantwoordingsorgaan geanalyseerd. De resultaten van deze inventarisatie zijn samengevat in tabel 4. Het valt direct op dat in relatief veel rapportages van het intern toezichthoudend orgaan $(22 \%)$ en van het verantwoordingsorgaan (26\%) het oordeel over de evenwichtige belangenafweging ontbreekt. In deze situaties wordt er veelal wel een algemeen oordeel gegeven over het door het bestuur gevoerde beleid, echter zonder een concreet oordeel over de evenwichtigheid van het beleid.

Tabel 4. Verantwoording door intern toezichthoudend orgaan en verantwoordingsorgaan.

\begin{tabular}{|c|c|c|c|c|c|}
\hline \multirow[t]{2}{*}{ Score } & \multirow[t]{2}{*}{ Omschrijving } & \multicolumn{2}{|c|}{ Verantwoording intern toezicht } & \multicolumn{2}{|c|}{$\begin{array}{c}\text { Verantwoording } \\
\text { verantwoordingsorgaan of } \\
\text { belanghebbendenorgaan }\end{array}$} \\
\hline & & Aantal & $\%$ & Aantal & $\%$ \\
\hline 0 & $\begin{array}{l}\text { Geen vermelding over de beoordeling van evenwichtige } \\
\text { belangenafweging }\end{array}$ & 11 & $22 \%$ & 13 & $26 \%$ \\
\hline 1 & $\begin{array}{l}\text { Alleen feitelijke vermelding dat de evenwichtige } \\
\text { belangenafweging is beoordeeld, zonder expliciet oordeel }\end{array}$ & - & - & - & - \\
\hline 2 & $\begin{array}{l}\text { Vermelding dat het beleid is beoordeeld en conclusie dat } \\
\text { dit niet evenwichtig is }\end{array}$ & - & - & - & - \\
\hline 3 & $\begin{array}{l}\text { Vermelding dat het beleid is beoordeeld en conclusie dat } \\
\text { dit deels evenwichtig is }\end{array}$ & 6 & $12 \%$ & 2 & $4 \%$ \\
\hline 4 & $\begin{array}{l}\text { Vermelding dat het beleid is beoordeeld en conclusie dat } \\
\text { dit evenwichtig is }\end{array}$ & 33 & $66 \%$ & 35 & $70 \%$ \\
\hline Totaal & & 50 & $100 \%$ & 50 & $100 \%$ \\
\hline
\end{tabular}

In de rapportages waaruit wel een expliciet oordeel wordt toegelicht door het intern toezichthoudend orgaan en verantwoordingsorgaan is dit oordeel meestal positief. Bij 33 pensioenfondsen $(66 \%)$ oordeelt het intern toezichthoudend orgaan dat het door het bestuur gevoerde beleid evenwichtig is, bij zes pensioenfondsen $(12 \%)$ is het oordeel dat het gevoerde beleid deels evenwichtig is.

Indien door het intern toezichthoudend orgaan opmerkingen worden gemaakt ten aanzien van de evenwichtige belangenafweging, dan hebben deze in veel gevallen betrekking op het premiebeleid en de hoogte van de premiedekkingsgraad. Een goed voorbeeld van een dergelijke toelichting is opgenomen in het verslag van de raad van toezicht van Stichting Bedrijfstakpensioenfonds voor de Betonproductenindustrie (figuur 4). Naast de duidelijke toelichting vinden wij het ook positief dat er een separate paragraaf in het verslag wordt gewijd aan de evenwichtige belangenafweging. Ook het intern toezichthoudend orgaan (in de vorm van niet-uitvoerende bestuurders) van Stichting Bedrijfstakpensioenfonds voor de Particuliere Beveiliging (figuur 5) heeft een separate paragraaf opgenomen in zijn verslag ten aanzien van de evenwichtige belangenafweging. Hier valt in positieve zin op dat er niet gebruik wordt gemaakt van algemene toelichtingen, maar dat er concreet bevindingen en aanbevelingen worden gerapporteerd.
Ten aanzien van de rapportages van het verantwoordingsorgaan concluderen wij dat de rapportages over het algemeen beknopt zijn. In de toelichting wordt relatief veel aandacht besteed aan procesmatige aspecten, zoals de omvang, kwaliteit en tijdigheid van de informatie die het bestuur aan het verantwoordingsorgaan heeft aangeleverd. Het valt op dat voor de toelichting op het eindoordeel van het verantwoordingsorgaan vaak gebruik wordt gemaakt van gestandaardiseerde teksten. In diverse rapportages van het verantwoordingsorgaan van verschillende pensioenfondsen zien wij vrijwel letterlijk dezelfde bewoordingen terugkomen. In deze toelichtingen wordt dan ook in één zin vermeld dat het bestuur een consistent beleid heeft gevoerd, waarbij de belangen van alle betrokkenen goed afgewogen en geborgd zijn. Hoewel dit oordeel op zichzelf natuurlijk informatief is voor de gebruiker van het jaarverslag, verdient het aanbeveling om nader te concretiseren op basis waarvan het verantwoordingsorgaan tot deze conclusie komt.

Een 'best practice' vinden wij terug in het verslag van het verantwoordingsorgaan van Stichting Pensioenfonds Xerox (figuur 6). Het verslag is met vier pagina's vrij omvangrijk en duidelijk gestructureerd. Per paragraaf wordt een onderwerp uitgelicht, bijvoorbeeld de formele positie en bevoegdheden van het verantwoordingsorgaan, een toelichting op de ontwikkelingen in boekjaar 
Figuur 4. Best practice toelichting verslag raad van toezicht: Stichting Bedrijfstakpensioenfonds voor de Betonproductenindustrie, Jaarverslag 2020, p. 50. https://www.betonpensioen.nl/Images/Jaarverslag\%202020.pdf

\section{Evenwichtige belangenafweging}

Evenwichtige belangenafweging is een belangrijk onderwerp voor zowel het bestuur als de raad. Dit onderwerp speelt een grote rol bij de discussies over de premie en pensioenopbouw in de komende jaren. Ook met het oog op het landelijke pensioenakkoord en de transitieperiode naar een nieuw pensioenstelsel is evenwichtigheid een belangrijk thema.

Vanaf het begin van 2020 is het bestuur reeds in overleg met de cao-partijen over de premie en de pensioenopbouw voor 2021 (en daarna). In deze gesprekken is door het bestuur nadrukkelijk aandacht gevraagd voor de lage premiedekkingsgraad, waardoor sprake is van een negatief effect op het herstel van het pensioenfonds. Helaas zijn de cao-partijen er samen niet uitgekomen om de uitgangspunten voor de pensioenregeling 2021 tijdig vast te stellen. Daardoor was het bestuur genoodzaakt om terug te vallen op eerder gemaakte afspraken. Ondanks dat de premiedekkingsgraad hierdoor nog ruim onder de streefwaarde van het bestuur ligt, vindt de raad het positief dat het bestuur een duidelijk signaal heeft afgegeven over het gewenste niveau en de mate waarin het bestuur een lage premiedekkingsgraad in de komende jaren nog acceptabel vindt vanuit een evenwichtige belangenafweging.

Eind 2020 heeft de overheid concept wetgeving gepubliceerd ten aanzien van het nieuwe pensioenstelsel. Omdat deze nieuwe wetgeving grote gevolgen zal hebben voor het fonds en de verschillende deelnemersgroepen, adviseert de raad het bestuur om zich hier goed op voor te bereiden. Dit kan bijvoorbeeld door op voorhand te inventariseren wat de potentiële wijzigingen concreet betekenen voor het fonds en te zorgen dat alle partijen binnen het fonds over voldoende kennis van zaken beschikken om straks de besluiten te kunnen nemen. De raad adviseert het bestuur dit traject goed voor te bereiden. De raad zal toetsen of het bestuur daarbij de beleidsafwegingen evenwichtig toepast.

Figuur 5. Best practice toelichting niet-uitvoerend bestuur: Stichting Bedrijfstakpensioenfonds voor de Particuliere Beveiliging, Jaarverslag 2020, p. 17. https://www.beveiligingspensioen.nl/sites/default/files/documenten/jaarverslag-2020.pdf

\section{De evenwichtige belangenafweging}

\section{Bevindingen}

- Het CDC-karakter van de regeling zorgt ervoor dat de wettelijk vereiste kostendekkendheid van de premie bereikt wordt door verlaging van de opbouw van de actieve deelnemer. Deze keuze van sociale partners zorgt ervoor dat het bestuur minder knoppen heeft waaraan ze kan draaien om eventuele onevenwichtigheden tegen te gaan. Bij de opdrachtaanvaarding is daar weliswaar bij stil gestaan maar het mag nooit een vanzelfsprekendheid worden.

- Bij een aantal "grote" besluiten wordt evenwichtigheid meegenomen in de afwegingen. Echter ook bij "kleinere" besluiten, bijvoorbeeld over het al dan niet maken van kosten, speelt evenwichtige belangenafweging een rol.

- Het bestuur heeft ten behoeve van het opstellen van het Jaarverslag 2019 in 2020 de discussie gevoerd wat de best passende toerekening van pensioenbeheerkosten is tussen "administratie" en "vermogensbeheer". Deze verdeling is passend, echter in de afweging is niet actief de vraag betrokken of de kostenverdeling voor actieven, inactieven en pensioengerechtigden verschillend uitwerkt.

\section{Aanbevelingen/actiepunten}

- Het blijft belangrijk zowel in de beleidsvoorbereiding als in de beeld- en besluitvorming aandacht te hebben voor evenwichtige belangenafweging.

2020, een overzicht met adviezen en een algemeen oordeel. Het oordeel van het verantwoordingsorgaan met betrekking tot het functioneren van het bestuur en de evenwichtige belangenafweging is ook opgenomen in een separate paragraaf. Hierbij zijn de speerpunten van het bestuur voor het boekjaar en de jaarlijks terugkeren- de onderwerpen opgenomen in een tabel. Per onderwerp is vervolgens het oordeel van het verantwoordingsorgaan weergegeven middels een 'smiley'. Tevens wordt per onderwerp vervolgens een korte toelichting gegeven. Wat ons betreft is dit een overzichtelijke en prettige presentatiewijze. 
Figuur 6. Best practice toelichting verslag verantwoordingsorgaan: Stichting pensioenfonds Xerox, Jaarverslag 2020, p. 27. https:// www.xeroxpensioenfondsen.nl/files/File/Jaarverslag\%20SPX_2020.pdf

\begin{tabular}{|c|c|c|}
\hline Terugkerende onderwerpen & $\begin{array}{l}\text { Oordeel } \\
\text { verantwoording } \\
\text { s-orgaan }\end{array}$ & Opmerkingen \\
\hline $\begin{array}{l}\text { Terugkerende onderwerpen, zoals } \\
\text { jaarverslag, communicatie, herstelplan, } \\
\text { begroting, rapportages en dergelijke }\end{array}$ & & $\begin{array}{l}\text { Deze onderwerpen zijn door het bestuur deugdelijk opgepakt, op } \\
\text { sommige onderdelen verbeterd en correct en tijdig behandeld dan } \\
\text { wel afgehandeld. }\end{array}$ \\
\hline $\begin{array}{l}\text { Evenwichtige belangenafweging voor } \\
\text { de verschillende doelgroepen van } \\
\text { deelnemers binnen het pensioenfonds }\end{array}$ & & $\begin{array}{l}\text { Het gaat er in eerste aanleg om dat alle belangen van de } \\
\text { verschillende groepen deelnemers goed zijn afgewogen. U iteraard } \\
\text { speelt ook behartiging van belangen hierbij een rol. } \\
\text { We stellen vast dat het bestuur bij belangrijke en/of relevante } \\
\text { bes luitvorming degelijk rekening houdt met een evenwichtige } \\
\text { belangenafweging. En deze waar nodig onderbouwt en goed vastlegt. }\end{array}$ \\
\hline
\end{tabular}

\subsection{Kwantitatieve mate van evenwichtigheid beleid}

Zoals in paragraaf 3.1 beschreven, kan op basis van een vereenvoudigd model vanuit de jaarverslagen afgeleid worden wat de financiële herverdelingseffecten tussen deelnemersgroepen in een jaar zijn als gevolg van een premiedekkingsgraad en beleidsdekkingsgraad die afwijken van $100 \%$ en afwijkende indexatiepercentages. Een premiedekkingsgraad lager dan $100 \%$ leidt tot een voordeel van de actieve deelnemers (inclusief het aandeel van de werkgever(s) en tot een nadeel voor gewezen en uitkerende deelnemers. Een beleidsdekkingsgraad lager dan 100\% is bij een ongekorte uitkering voordelig voor de uitkerende deelnemers en benadeelt de actieve en gewezen deelnemers. Bij percentages boven de 100\% geldt dit verband tegengesteld. Ook een indexatiebeleid met verschillende toeslagen per groep deelnemers kan tot herverdelingseffecten leiden. Omdat het hier om herverdelingseffecten tussen deelnemersgroepen gaat, is het saldo van deze effecten op het niveau van het pensioenfonds per definitie nihil.

Voor de pensioenfondsen die deel uitmaken van de onderzoekspopulatie hebben wij de herverdelingseffecten berekend over de boekjaren 2020 en 2019, en vervolgens uitgedrukt in een percentage van de voorziening pensioenverplichtingen ultimo boekjaar. Dit leidt tot het in tabel 5 opgenomen beeld met het gemiddelde van de berekende herverdelingseffecten en bijbehorende standaarddeviaties. In figuur 7 hebben we de afzonderlijke herverdelingseffecten voor actieve deelnemers en uitkerende deelnemers opgenomen, voor zowel 2020 als 2019.

Uit tabel 5 en figuur 7 blijkt dat de gemiddelde effecten niet groot zijn. Dit wordt veroorzaakt doordat de media-

Tabel 5. Gemiddelde van herverdelingseffecten per deelnemersgroep.

\begin{tabular}{|c|c|c|c|c|}
\hline \multirow[t]{2}{*}{ Deelnemersgroep } & \multicolumn{4}{|c|}{$\begin{array}{l}\text { Herverdelingseffecten per deelnemersgroep als percentage van voorziening } \\
\text { pensioenverplichtingen }\end{array}$} \\
\hline & Gemiddeld 2020 & $\begin{array}{l}\text { Standaarddeviatie } \\
2020\end{array}$ & Gemiddeld 2019 & $\begin{array}{l}\text { Standaarddeviatie } \\
\qquad 2019\end{array}$ \\
\hline Actieve deelnemers (inclusief aandeel werkgever(s) & $0,06 \%$ & $0,52 \%$ & $0,04 \%$ & $0,50 \%$ \\
\hline Gewezen deelnemers & $0,03 \%$ & $0,27 \%$ & $0,11 \%$ & $0,31 \%$ \\
\hline Uitkerende deelnemers & $-0,09 \%$ & $0,38 \%$ & $-0,15 \%$ & $0,42 \%$ \\
\hline
\end{tabular}

ne premiedekkingsgraad in 2020 93,9\% (2019: 100,0\%) bedraagt, en de beleidsdekkingsgraad in $2020101,7 \%$ (2019: 107,2\%). Over 2020 wordt het voordeel voor de actieve deelnemers $(0,06 \%)$ met name veroorzaakt door een mediane premiedekkingsgraad onder de $100 \%$. Over 2019 wordt het beperkte voordeel $(0,04 \%)$ voor de actieve deelnemers met name veroorzaakt door een mediane beleidsdekkingsgraad boven de 100\%. Hierdoor stijgt bij elke uitkering (tegen 100\%) de relatieve beleidsdekkingsgraad. ${ }^{3}$ Uit de standaarddeviatie blijkt echter wel een behoorlijke spreiding. Zoals te zien is in figuur 7 wordt dat met name veroorzaakt door een beperkt aantal fondsen, bij de meeste pensioenfondsen zijn de herverdelingseffecten minder dan $0,5 \%$.

Een vervolgvraag is of bij die pensioenfondsen waar de herverdelingseffecten relatief groot zijn, er in het jaarverslag uitgebreider stil wordt gestaan bij de evenwichtige belangenafweging die heeft plaatsgevonden. Om deze vraag te beantwoorden hebben wij de verantwoording bij de vijf pensioenfondsen met de grootste herverdelingseffecten beoordeeld. Bij deze vijf fondsen is de herverdeling het effect van hetzij een hoge premiedekkingsgraad ( $>145 \%$, betreft drie fondsen) hetzij een combinatie van een lage premiedekkingsgraad $(<65 \%)$ met een hoge beleidsdekkingsgraad $(>120 \%$, betreft twee fondsen). Deze laatste twee fondsen kunnen zich vanuit hun gezonde vermogenspositie een verlies op premie permitteren. De eerste drie fondsen kennen hetzij een bijstortverplichting (één fonds) hetzij een expliciete premie ter borging van indexaties of ter opbouw van het weerstandsvermogen. De verantwoording door het bestuur bij deze vijf fondsen is beperkt tot 
Figuur 7. Herverdelingseffecten per deelnemersgroep over 2020 en 2019 als percentage van voorziening pensioenverplichtingen.

\section{Herverdelingseffect per deelnemersgroep over 2020 en 2019 als percentage van voorziening pensioenverplichting}

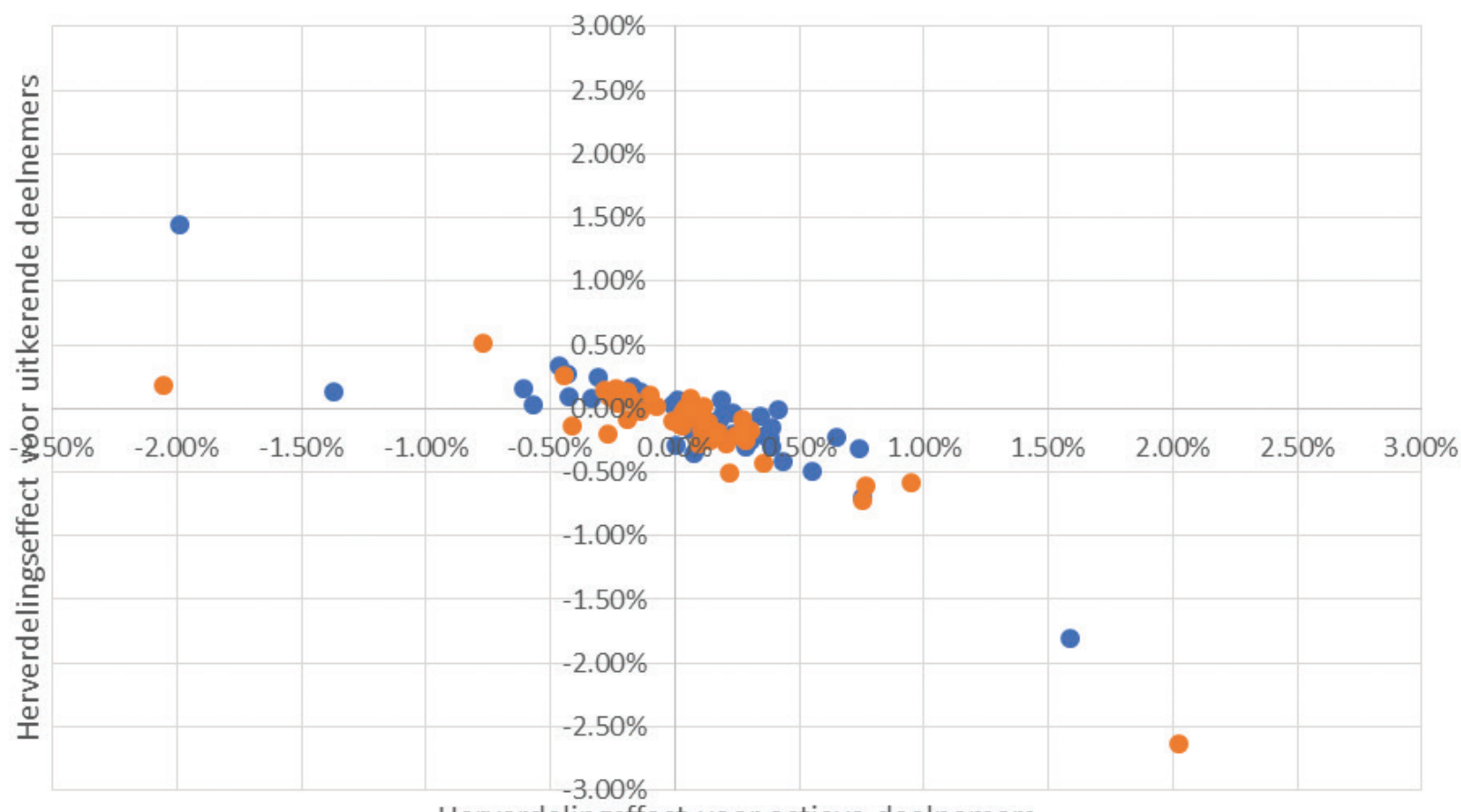

Herverdelingsffect voor actieve deelnemers

de vermelding dat het beleid evenwichtig is, maar geeft daar geen verdere onderbouwing van. Bij drie van de vijf fondsen is zowel het intern toezicht als het verantwoordingsorgaan van oordeel dat het beleid evenwichtig is, bij de andere twee fondsen is of het intern toezicht of het verantwoordingsorgaan dit oordeel toegedaan en ontbreekt het oordeel van het andere orgaan.

Ten tweede hebben wij beoordeeld of verschillende scores voor de verantwoording door het bestuur, het intern toezicht en het verantwoordingsorgaan samenhangen met de gemiddelde omvang van de herverdelingseffecten bij de desbetreffende pensioenfondsen. De onderzoeksresultaten tonen echter geen eenduidig beeld. Daarmee hebben wij geen verband kunnen vaststellen tussen de omvang van de herverdelingseffecten en de kwaliteit van de verantwoording over de evenwichtige belangenafweging.

\section{Conclusie en nabeschouwing}

In deze bijdrage hebben wij de kwaliteit van de verantwoording over de evenwichtige belangenafweging in de jaarverslagen 2020 van vijftig pensioenfondsen beoordeeld. Wij concluderen dat de toelichtingen ten aanzien van de evenwichtigheid van het gevoerde beleid over het algemeen beperkt zijn en daarmee voor verbetering vatbaar. Dit ziet vooral toe op de verantwoording door het bestuur zelf. De grote meerderheid (70\%) van de pensioenfondsen heeft in het jaarverslag 2020 geen toelichting ten aanzien van de evenwichtige belangenafweging opgenomen, of alleen een korte vermelding dat het beleid evenwichtig is. Van de onderzochte fondsen geeft 30\% een kwalitatieve duiding van de evenwichtige belangenafweging die heeft plaatsgevonden, geen enkel fonds onderbouwt dit met kwantitatieve informatie. Met betrekking tot het intern toezichthoudend orgaan en het verantwoordingsorgaan wordt in $78 \%$ respectievelijk $74 \%$ van de rapportages vermeld of het orgaan van mening is dat het beleid (deels) evenwichtig is, maar ook hier geldt dat de toelichtingen beknopt zijn. Uit ons onderzoek blijkt tevens dat de herverdelingseffecten tussen de verschillende deelnemersgroepen in de boekjaren 2020 en 2019 relatief beperkt zijn. Mogelijk is dit een verklaring voor de beperkte toelichtingen die wij terugvinden in de desbetreffende jaarverslagen.

Gezien het belang van een evenwichtige belangenafweging door het pensioenfondsbestuur, zou het naar onze mening passend zijn om in de Pensioenwet (en op basis daarvan tevens in de verslaggevingsstandaard RJ 610 Pensioenfondsen) op te nemen dat pensioenfondsen in hun bestuursverslag de evenwichtige belangenafweging 
expliciet dienen toe te lichten. Dit geldt eens temeer in de aanloop naar het nieuwe pensioenstelsel, waar de evenwichtige belangenafweging een belangrijke rol speelt in het transitieproces (met als ultiem moment het invaren van de huidige aanspraken in het nieuwe stelsel). Wij roepen pensioenfondsen op de verantwoording ten aanzien van de evenwichtige belangenafweging in de jaarverslaggeving te verbeteren. Naar onze mening kan dit worden bereikt door in het bestuursverslag een separate paragraaf te wijden aan dit thema, en de toelichting vervolgens gestructureerd uit te werken. Het verdient aanbeveling de toelichting op te bouwen vanuit de missie en visie van het pensioenfonds. Vervolgens kan worden toegelicht hoe het bestuur is samengesteld in relatie tot de evenwichtige be- langenafweging. Een deskundig en divers samengesteld bestuur draagt immers bij aan een evenwichtig besluitvormingsproces, waarbij de bestuursleden oog hebben voor de belangen van de verschillende deelnemersgroepen. Tot slot kan een toelichting worden opgenomen ten aanzien van onder andere de risicohouding, het beleggingsbeleid (inclusief renteafdekking), premiebeleid en toeslagbeleid in relatie tot de evenwichtige belangenafweging. Waar mogelijk kunnen dit beleid, en de gevolgen van dit beleid voor de verschillende deelnemersgroepen, onderbouwd worden met kwantitatieve informatie. Een dergelijke, goed gestructureerde toelichting op de evenwichtige belangenafweging draagt op deze wijze concreet bij aan de informatiewaarde van het jaarverslag.

Drs. W. (Wilfred) Kevelam RA is partner bij KPMG Accountants en geeft leiding aan de sectorgroep Pensions Audit. Daarnaast is hij als universitair docent Externe Verslaggeving verbonden aan de Rijksuniversiteit Groningen en lid van de werkgroep Accounting van de Europese brancheorganisatie PensionsEurope.

- Drs. A. (Anne) Laning RA RC is founding partner bij \&Amp Borg en vervult diverse functies op het snijvlak van bestuur, toezicht en internal audit in de pensioensector en daarbuiten. Daarnaast is hij als docent verbonden aan de Nyenrode Business Universiteit, Hanzehogeschool en SPO en actief bij de NBA en het IIA.

\section{Dankwoord}

De auteurs danken Debora Leboraga, student-assistent aan de vakgroep Accountancy van de Rijksuniversiteit Groningen, voor haar waardevolle bijdrage aan het empirisch onderzoek.

\section{Noten}

1. Een aantal pensioenfondsen valt niet onder de Pensioenwet, maar onder de Wet verplichte beroepspensioenregeling. Op deze fondsen zijn de voorschriften uit RJ 610 en de Code Pensioenfondsen naar analogie van toepassing.

2. Merk op dat hier de toekomstige deelnemers van een fonds niet expliciet genoemd worden.

3. Bij publicaties in de pers wordt vaak uitgegaan van ABP en PFZW, deze kennen lagere dekkingsgraden dan de hier genoemde mediane beleidsdekkingsgraad en premiedekkingsgraad. Bij deze fondsen zijn daardoor ook de herverdelingseffecten groter, met maximaal $0,39 \%$ voordeel voor de actieve deelnemers in ABP over 2020.

\section{Literatuur}

- Den Blanken CJ, Panneman D (2018) Evenwichtige belangenafweging als uitdaging. Pensioen Magazine, december, 17-22. https:// www.sprenkelsenverschuren.nl/media/publicaties/den_blanken-panneman.pdf

- DNB (De Nederlandsche Bank) (2021) statistieken, https://www. dnb.nl/statistieken/data-zoeken/\#/?current=actueel\&kindofproduct $=$ mainproduct\&statistics_type $=$ toezichtdata\&theme $=$ pensioenfondsen (gegevens onttrokken 4 april 2021)

- Kamerbrief vrijstellingsregeling en transitie-FTK, 16 december 2020, rijksoverheid. https://www.rijksoverheid.nl/documenten/ kamerstukken/2020/12/16/brief-vrijstellingsregeling-en-het-transitie

- Langendijk HPAJ, Laning A (2011) Pensioenfondsen: voldoende verantwoording in hun jaarverslag omtrent beleggingsbeleid, pre- miebeleid en toeslagbeleid? Maandblad voor Accountancy en Bedrijfseconomie 85(12): 678-691. https://doi.org/10.5117/mab.85.13900

- NBA (Koninklijke Nederlandse Beroepsorganisatie van Accountants) 23 februari 2021. Open brief Pensioenen. https://www.nba.nl/ nieuws-en-agenda/nieuwsarchief/2021/februari/svp-publiceert-eenupdate-van-de-open-brief-pensioenen/

- Ter Hoeven RL, Laning A (2010) Het echec van IAS 19 in Nederland verklaard. Maandblad voor Accountancy en Bedrijfseconomie 84(1/2): 649-657. https://doi.org/10.5117/mab.84.13889

- Wetsvoorstel 'Wet toekomst pensioenen', geraadpleegd op www. internetconsultatie.nl/wettoekomstpensioenen 


\section{Bijlage 1}

Overzicht pensioenfondsen in de onderzoekspopulatie.

\begin{tabular}{|c|c|}
\hline Stichting Pensioenfonds van de ABN AMRO Bank N.V. & Stichting Pensioenfonds Alliance \\
\hline Stichting Pensioenfonds APF & Stichting Pensioenfonds Openbare Apothekers \\
\hline Stichting Pensioenfonds voor de Architectenbureaus & Stichting Pensioenfonds Avery Dennison \\
\hline Stichting Bedrijfstakpensioenfonds voor de Betonproductenindustrie & Stichting Pensioenfonds Cargill B.V. \\
\hline Stichting Pensioenfonds Croda & Stichting Dow Pensioenfonds \\
\hline Stichting Pensioenfonds Ecolab & Stichting Pensioenfonds Forbo \\
\hline Ring K van Stichting Pensioenfonds PON (Gazelle) & Stichting Pensioenfonds voor de Nederlandse Groothandel \\
\hline Stichting Pensioenfonds HAL & Stichting Heineken Pensioenfonds \\
\hline Stichting Pensioenfonds Honeywell & Stichting Pensioenfonds Hoogovens \\
\hline Stichting Bedrijfstakpensioenfonds voor de Houtverwerkende industrie & Stichting Bedrijfstakpensioenfonds voor het Kappersbedrijf \\
\hline Stichting Algemeen pensioenfonds KLM & Stichting Pensioenfonds Vliegend Personeel KLM \\
\hline Stichting Pensioenfonds voor de Koopvaardij & Kring Bavaria van Stichting Achmea Algemeen Pensioenfonds \\
\hline Kring CK1 van Stichting Het Nederlandse Pensioenfonds & $\begin{array}{l}\text { Kring Forward van Stichting Algemeen Pensioenfonds Unilever } \\
\text { Nederland }\end{array}$ \\
\hline Stichting Pensioenfonds Lloyd's Register Nederland & Stichting Beroepspensioenfonds Loodsen \\
\hline Stichting Pensioenfonds Medewerkers Apotheken & Stichting Pensioenfonds Medische Specialisten \\
\hline Stichting Metro Pensioenfonds & Stichting Molenaarspensioenfonds \\
\hline Stichting Nedlloyd Pensioenfonds & Stichting Pensioenfonds NIBC \\
\hline Stichting Pensioenfonds Notariaat & Stichting Bedrijfstakpensioenfonds voor de Particuliere Beveiliging \\
\hline Stichting Pensioenfonds van de Metalektro & Stichting Pensioenfonds Rail \& OV \\
\hline Stichting Bedrijfspensioenfonds voor de Rijn- en Binnenvaart & Stichting Pensioenfonds SABIC \\
\hline Stichting Sportfondsen Pensioenfonds & Stichting Pensioenfonds TNT Express \\
\hline Pensioenfonds DHL Nederland & Stichting Pensioenfonds voor Verloskundigen \\
\hline Stichting Bedrijfstakpensioenfonds Waterbouw & Stichting Will Niemeijer Pensioenfonds \\
\hline Stichting Pensioenfonds Wolters Kluwer Nederland & Stichting Pensioenfonds Xerox \\
\hline Stichting Bedrijfstakpensioenfonds Zorgverzekeraars & $\begin{array}{l}\text { Stichting Bedrijfstakpensioenfonds voor de Zuivel en aanverwante } \\
\text { industrie }\end{array}$ \\
\hline
\end{tabular}

